\title{
Customer Relationship Management (CRM) Based On Web To Improve The Performance Of The Company
}

\author{
Adiyanto ${ }^{1}$, Nurasiah ${ }^{2}$ \\ Dosen Sistem Informasi STMIK Insan Pembangunan ${ }^{1,2}$ \\ Jl. Raya Serang Km. 10 Pos Bitung, Kota Tangerang, Banten \\ Email : Adiet031170@gmail.com, nurash ip@yahoo.com
}

To cite this document:

Adiyanto, A., \& Nurasiah, N. (2019). Customer Relationship Management (CRM) Based on

Web to Improve the Performance of the Company. IAIC Transactions on Sustainable Digital

Innovation, 1(1), 32-41. Retrieved from https://aptikom-

journal.id/index.php/itsdi/article/view/7

\begin{abstract}
Customer relationship management (CRM) is one of the model that can be used to maintain the relationship between customer and company. CRM is really helpful for the company to increase the customer interest toward the company, improve the economic condition, and improve the product promotion through the use of intimate customer knowledge. But, most of the company still can't utilize CRM well, one of the problems is to increase the company performance. In this Journal will talk about the utility of CRM based on web to increase the company performance, the method that used in this journal is waterfall method which includes, analysis and systems engineering, requirements analysis, design, coding, programming, implementation and maintenance, and also literature review. With the e-CRM application is expected to provide benefits of the company, helps companies to know the wishes of customers, and can monitor the performance of employees, so the company is able to improve the performance of the company.
\end{abstract}

Key words: Customer Relationship Management, Customer Satisfaction, Company Performance, waterfall.

\section{Introduction}

With the rapid development of technology and increasingly significant business growth, the need for things closely related to the customer's relationship is also increasingly needed. The increasing business competition facing many companies today focuses on how companies attract new customers and retain existing customers. In order to survive and succeed in dealing with it is necessary a good relationship between the company and the customer. Customer Relationship Management (CRM) is one of the business approaches that is based on relationship management or customer relationships. CRM is the business of a company to concentrate on maintaining customers (so as not to run to competitors) by collecting all forms of customer interaction either by phone, email, feedback on the site or the results of talks with sales staff and Marketing [1]. CRM focuses more on what customers are rated not to products

that companies want to sell. With the development of today's technology, the Internet can become one of the media for the company to maintain customer relationships, the Internet is able to provide access to the company in order to continue to connect with customers in time and distance Unlimited. 


\section{IAIC Transactions on Sustainable Digital Innovation (ITSDI)}

Vol. 1 No. 1 October 2019

Unfortunately there are still many companies that do not utilize the Internet-based Customer Relationship Management or known as E-CRM well, customers have difficulty in obtaining information and also convey complaints to the company. Many companies just use social media as a media for the delivery of information, complaints and criticism from its customers, and also took a long time for the employee to respond to complaints from the customer. Employee performance is also an important factor in maintaining customer relationships, with adequate number of employees and good competence, employees are able to serve customers well. If the customer's interest in the company's services decreases, it can threaten the financial stability of a company.

Therefore, good Internet utilization is needed in the implementation of Customer Relationship Management, one of which is with the implementation of a Web-based Customer Relationship Management. With this web-based CRM is expected to be able to provide convenience for customers to communicate with the company, and also can help the company to know the wishes of the customer deeply, so that the company is able to know anything necessary for the company to improve its performance, with good performance the company will be able to retain old customers and acquire new customers.

Previous research conducted by Cindy Claudia, Michael Suyanto, Fransiska Prihatini Sihotang, in 2018 with the title "Customer Relationship Management information System on CV. Shannon Otopart Palembang" This research discusses still not Media that can be used by customers of CV. Shannon Otopart to get detailed information about the amount of stock of goods, the price of goods, and discounts that exist, but still no media for ordering, so it takes a long time Ordering and recording of goods is inaccurate. The result of this research is an information system that can assist customers in obtaining information on ordering goods, and help companies in the registration of goods and orders [2]. Further research was done by Heru Saputro, Teguh Tamrin in the year 2018 with the title "Customer Relationship Management implementation for the customer service optimization traditional food Rengginang Web based and Tawk" This study discusses About website design that can be used in information delivery and ordering traditional food Rengginang on micro Small business. The result of this research is a website with a www.marvel-shop.com address that can be used as a media selling information to the public [3]. The last of the research conducted by Ni Luh Manik Sugiarni, Dian Pramana, Ni Nyoman Harini Puspita in 2015 with the title "Implementation of CRM (Customer Relationship Management) on the Travel information System X WEB-based" This study discusses Transaction recording and data processing on travel $x$ still using manual way, so it takes long time and the data is inaccurate, so it can reduce the interest of the customers, the result of this research is the information system That can manage transaction data and other data can be done quickly, so service to customers can also be more effective and efficient [4].

Of the 3 studies that have been conducted there is a difference with this research, which is the above research focuses on delivering information and data processing in the company, while in this research focuses on the needs of communication media, Between the company and the customer, so that all complaints, criticism, and suggestions from customers can be kept neatly, and can be used by the company in decision making.

To better understand the problems and problem solving of Customer Relationship Management (CRM) Web-based, it can be described in a concept map. According to Huda (2010) The concept map is one part of the organizational strategy. Organizational strategy aims to help students improve the meaningfulness of organizational materials aimed at helping students improve the meaningfulness of new materials, especially by introducing organizing structures New to these materials. Organizational strategies can consist of re-grouping ideides or terms or dividing ideas or terms into smaller subsets [11]. 


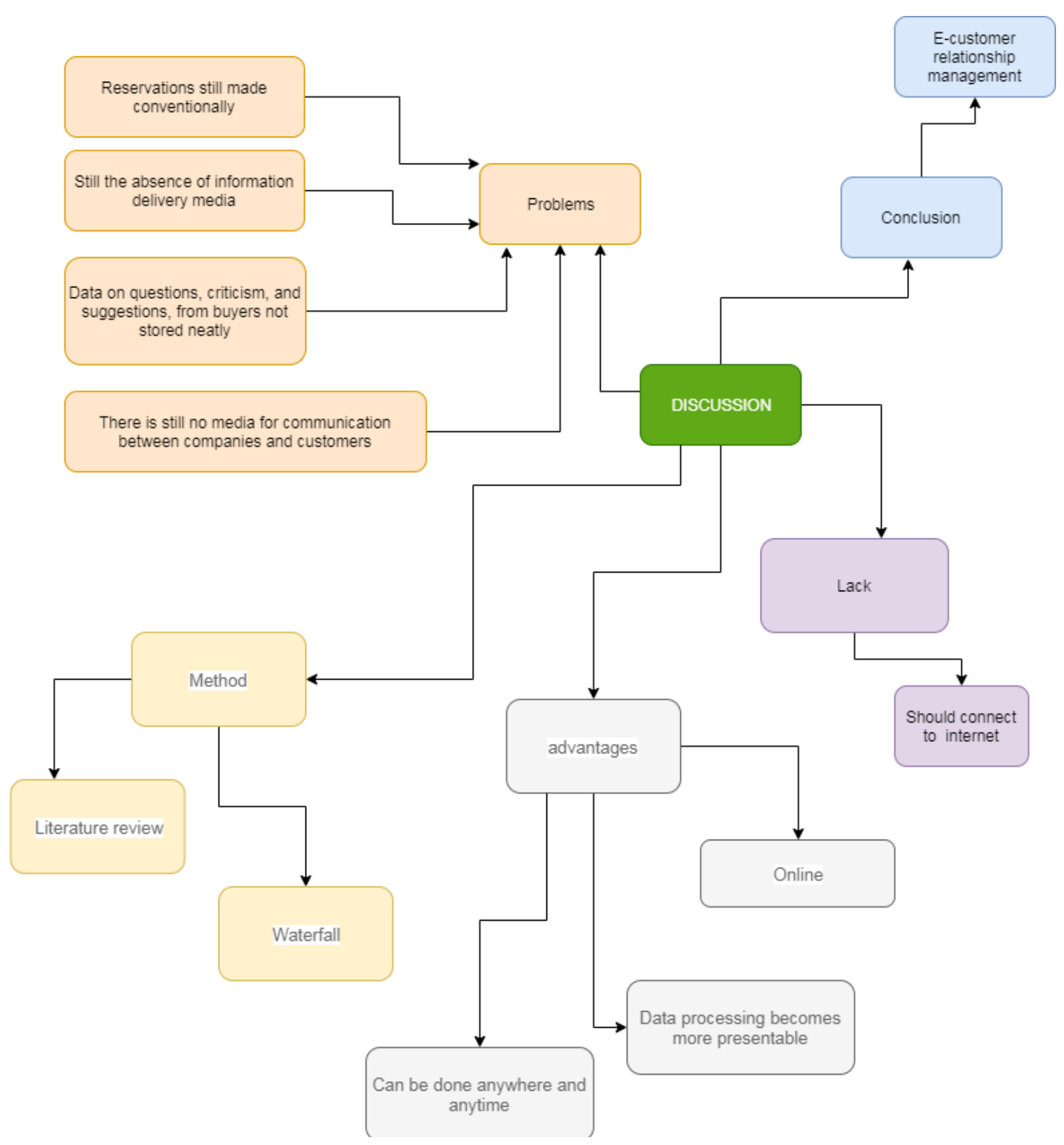

Figure 1. Mind Mapping

Based on Mindmap can be concluded that the solution that can be used in solving problems in this research is a Customer Relationship Management information system that has an advantage that is, can be accessed online, can be Manage data so that data storage can be more neat, and can be done anywhere and anytime, but there are disadvantages in this system that is when the user does not have Internet network then the system can not be used. The purpose of this mindmap is to assist the author in conducting analysis.

\section{Research Method}

The research method used in this research refers to 2 (two) data collection techniques,

\section{namely:}

\subsection{Waterfall Method}

According to Pressman (2015:42), the waterfall model is a classic model with a systematic nature, in order to build software. This Model is also commonly referred to as the "classic life cycle". This model is included in the generic model of software engineering and was first 


\section{IAIC Transactions on Sustainable Digital Innovation (ITSDI)}

Vol. 1 No. 1 October 2019

introduced by Winston Royce around the year 1970 so it is often considered old-fashioned, but is the most widely used model in Software Engineering (SE) [5]. The Waterfall method phases are:

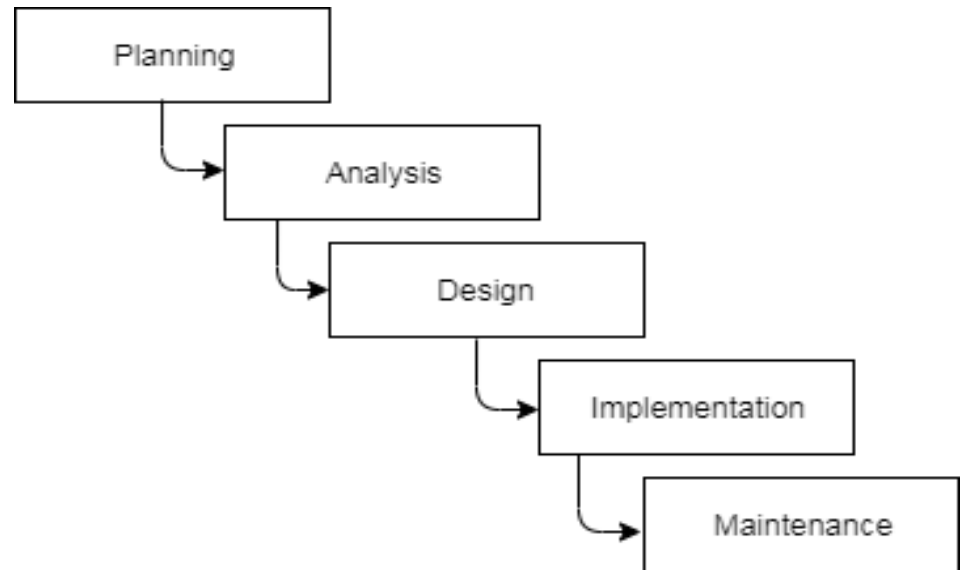

Figure 2. Waterfall Flow Method

Waterfall model is one of the software development models, where the progress of a process is seen as continuing to flow down like a waterfall.

Stage - The development stage of waterfall model is:

1. Planning

At this stage emphasizes the collection of user needs and illustrates the concept of relationship between user Degan interface. That will generate a specification of the system of Web-based customer relationship management.

2. Analysis

At this stage is conducting analysis of the data needed in designing the system from the existing concept.

3. The design

At this stage the results of the analysis that has been done will be created as a draft system in the form of diagram UseCase, class diagram, and sequence diagram.

4. Implementation

At this stage, system design is realized with a series of programs or program units. Then the program unit is tested to see if the unit of the program is in accordance with its specifications. Designing a program unit at this stage uses the PHP programming language, and still uses the local server.

5. Maintenance

At this stage it takes the longest time, this maintenance is done after the system is implemented (applied) and used. Maintenance includes checking of some errors that were not found at the previous stage, improvements to system implementation and system service development.

\subsection{Library Study method}

Many research that has been discussed about Customer Relationship Management that can be used as a data source. Here are some literature reviews that are used as the source of the center, among others:

1. This research was conducted by Akhmad Izzudin Amin, Erlan Darmawan, and Heru Budianto in the year 2016 titled "Implementation of CRM (Customer Relationship Management) on the Web based photography reservation information system at Aini Photo Brass Shop". In this research the author presents an analysis of the development of web-based CRM that can be used by customers in booking photography and purchase transactions photographic equipment, so as to improve the quality of service to Customer [6]. 


\section{IAIC Transactions on Sustainable Digital Innovation (ITSDI)}

Vol. 1 No. 1 October 2019

2. The research was conducted by Abdul Ariga Rahman, Ahmad Supaidi, Iziah Aslamiah, and Ali Ibrahim in 2018 under the title "Implementation of Customer Relationship Management (CRM) customer service (Corporate) BGES division at PT Telkom Witel Sulsel". This research aims to address the problems faced by PT Telkom Witel Sulsel which is notice of payment to customers who often experience delays, so that the company suffered losses, the results are in the get from the research This is a payment notification information system to customers [7].

3. The research was conducted by S. Freddy's in 2014 under the title "Customer Relationship Management Performance measurement Model in the banking industry". The research aims to obtain a model of performance measurement of CRM in the banking industry efficiently and effectively. The results derived from this study are the CRM Scorecard which is one of the right approach models in measuring the performance of a CRM-based information technology [8].

4. The research was conducted by Augustine Ivan Suryadi, Yulia Yulia, and Anita Nathania Purbowo in 2017 under the title "The creation of a Website-based Customer Relationship Management application to help sales and analysis of bicycle manufacturers." This research aims to create a system that can be used to monitor the performance of bicycle sales agents, facilitate business processes and analyze the sale of goods. The results gained from this research are an information system that can help producers monitor the performance of agents and manage company data [9].

5. This research was conducted by Syamsul Bahri, Sopiyan Dalis in the year 2018 titled "Design of Web-based E-Enrollment using Customer Relationship Management (CRM) at the Integrated Islamic Elementary School." This study aims to Develop a web-based information system using CRM in managing student data and delivering information to students at an integrated Islamic elementary school [10].

Of the 5 (five) literature that became the basis of research can be concluded that there is no Customer Relationship Management system that focuses on the utilization of the system as a media communication or submission of questions, criticism, and suggestions that want to be conveyed to the company, so that the data can be stored neatly and can be used by management in the decision-making process to improve the company's performance.

\section{Findings}

3.1. System design.

Based on the research that has been conducted, several system needs are outlined in the form of a Use Case diagram.

\subsubsection{Diagram Class}

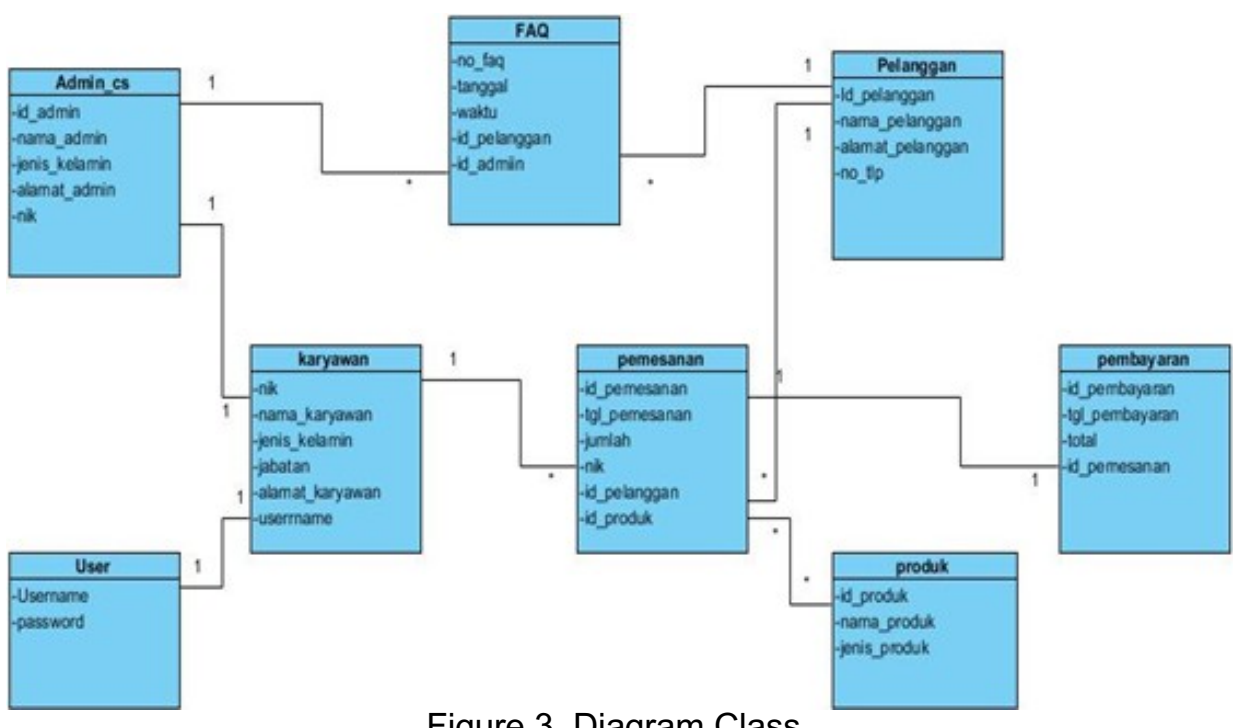

Figure 3. Diagram Class 
IAIC Transactions on Sustainable Digital Innovation (ITSDI)

Vol. 1 No. 1 October 2019

Figure 3, is a Diagram Class of information System Customer Relationship Management which is to describe the path of relationship between users in the system.

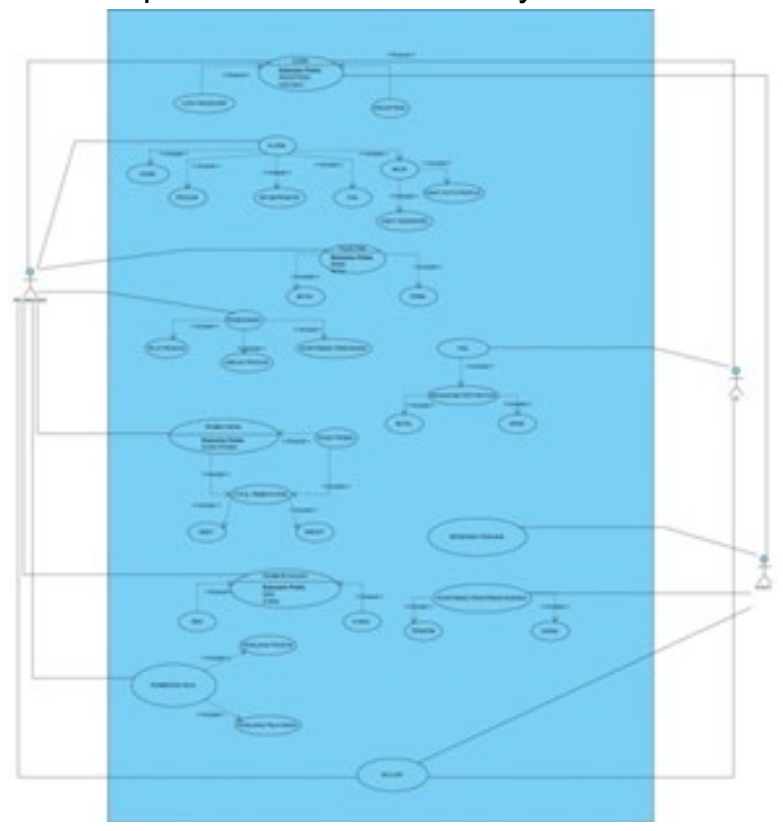

Figure 4. Use Customer Diagram Case

Figure 4, is the use case diagram of information system Customer Relationship Management that describes the relationship between customers with a system that is running on the use case there are 3 (three) actors, namely Customer, Admin CS, and employees.

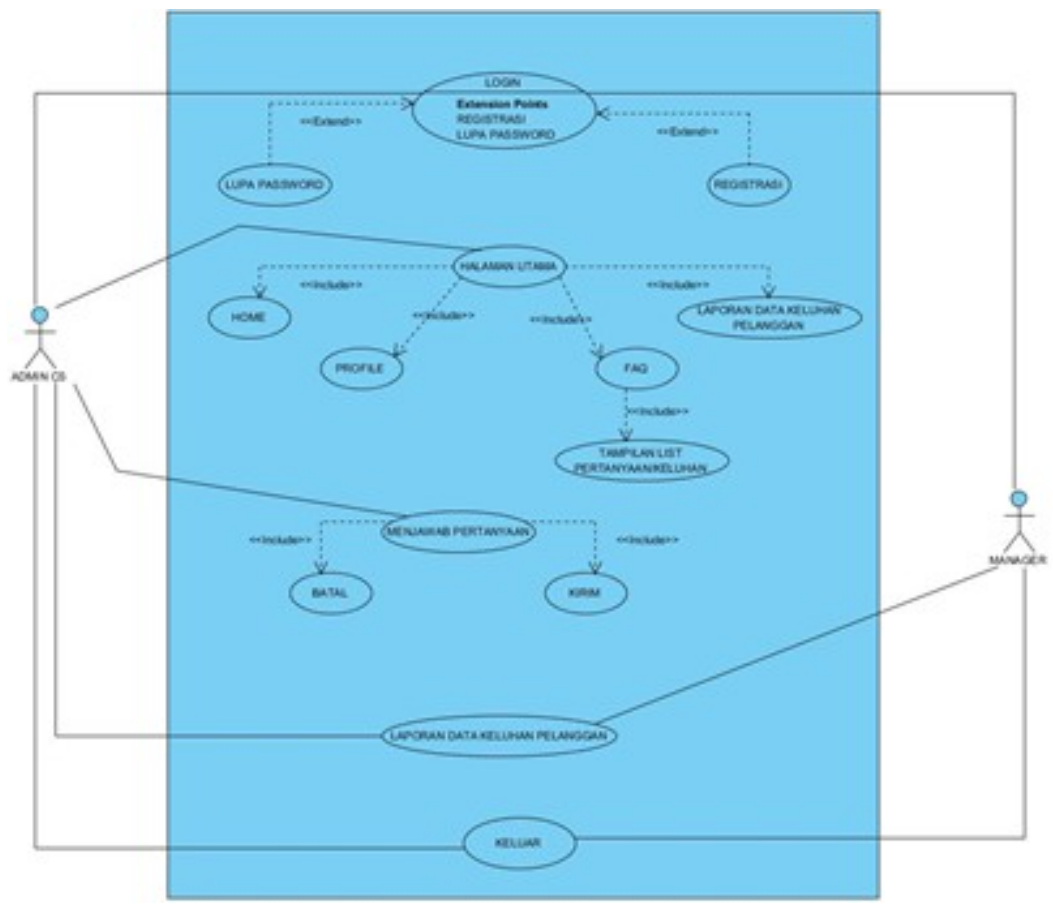

Figure 5. Use the CS Admin Diagram Case 
IAIC Transactions on Sustainable Digital Innovation (ITSDI)

Vol. 1 No. 1 October 2019

Figure 5, is the use case diagram of information system Customer Relationship Management describing the relationship between CS Admin and manager with the running system, on the use case there are 2 (two) actors, namely the CS Admin, and manager.

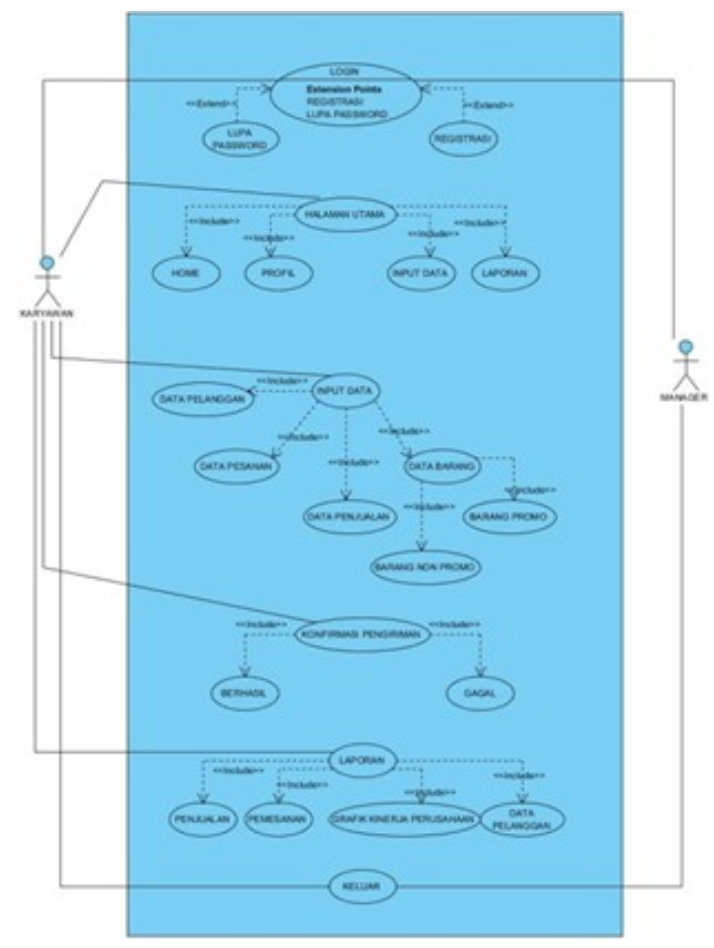

Figure 6. Use Employee Diagram Case

Figure 6, is the use case diagram of information system Customer Relationship Management describing the relationship between employees and managers with the system that runs on the use case there are 2 (two) actors, namely employees, and managers.

\subsubsection{Sequence Diagram}

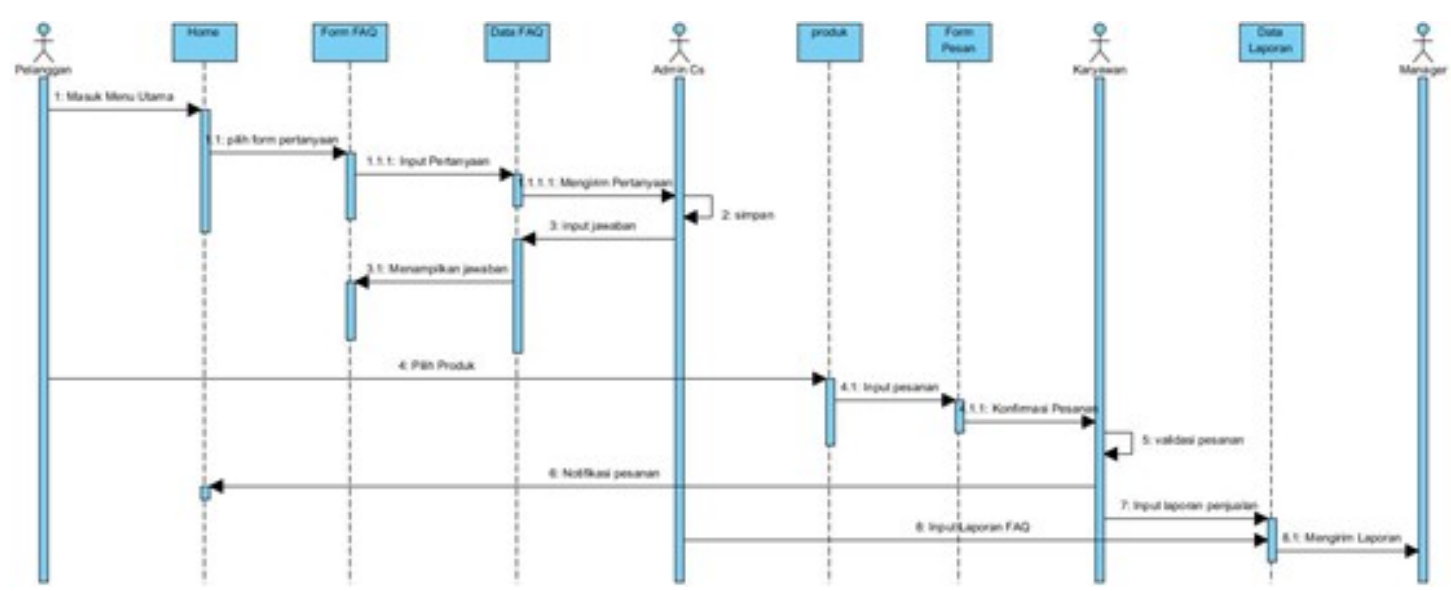

Figure 7. Sequence Diagram 
IAIC Transactions on Sustainable Digital Innovation (ITSDI)

Vol. 1 No. 1 October 2019

Figure 7, is a sequence diagram of information system Customer Relationship Management that describes the flow of customer, admin CS, employees, and managers in conducting activities in the system.

\subsection{System Implementation}

For the application of programs in this research web is still in the design phase of the system by using HTML programming language and operated via localhost.

\subsubsection{Customer Login page display}

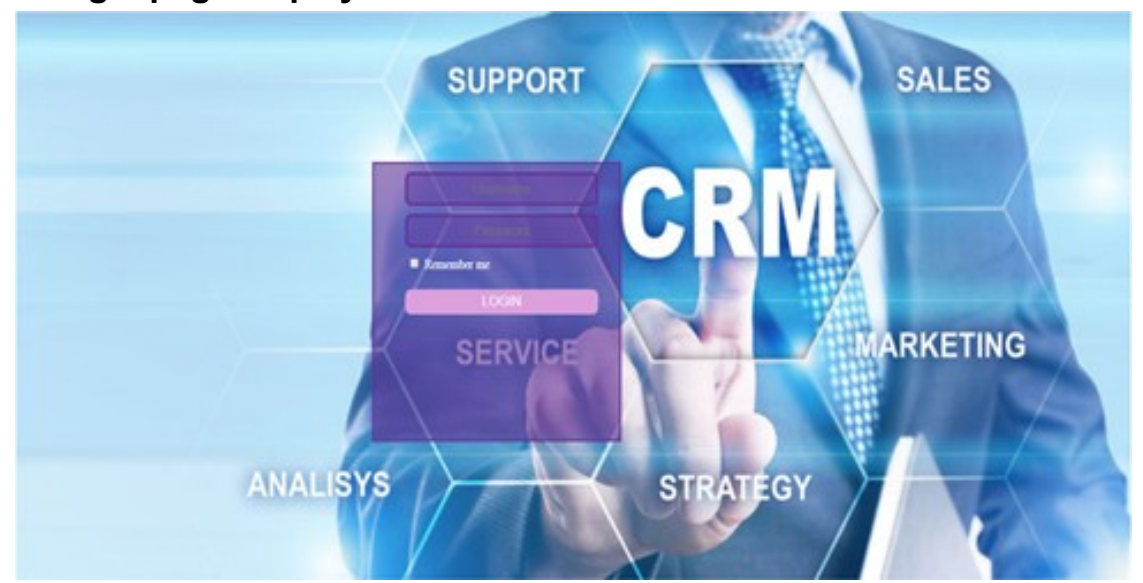

Figure 8. is the customer login view.

Figure 8 , is the page that first appeared when the user accesses the system, the user is obliged to fill in the data in the form of username and password to be able to enter the main page, and if the user fails to enter the username and password then the system will display User notification failed

login.

\subsubsection{Display of Customer FAQ page}

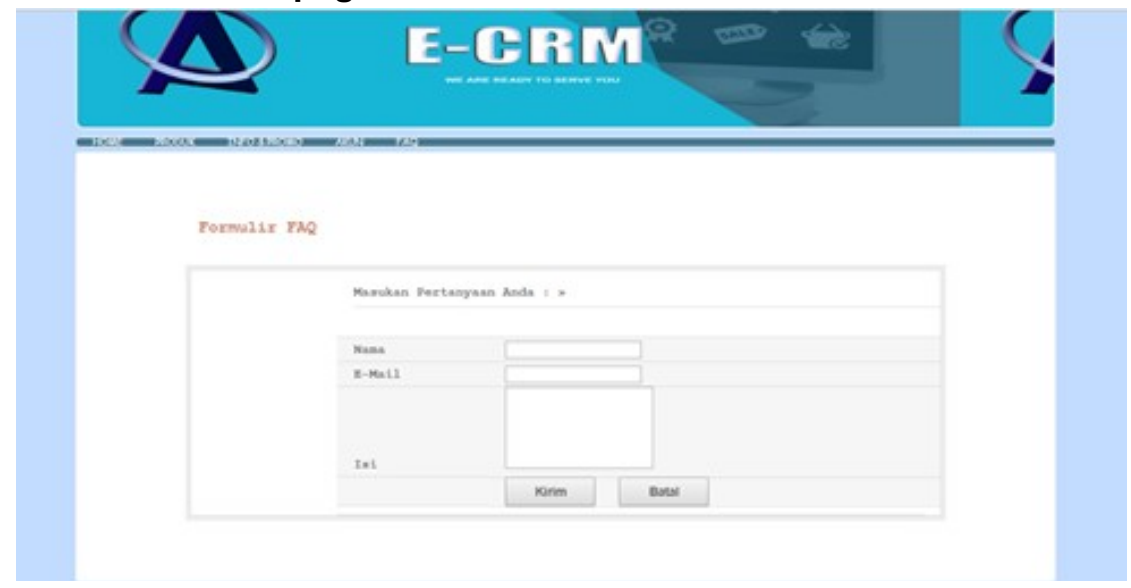

Figure 9. FAQ page views

Figure 9, is the display of the FAQ page where the user fills Name, e-mail, and any questions or criticism that you want to convey to the company. Through this page the user can communicate with the CS admin. 
IAIC Transactions on Sustainable Digital Innovation (ITSDI)

Vol. 1 No. 1 October 2019

\subsubsection{Home Page view of CS Admin}

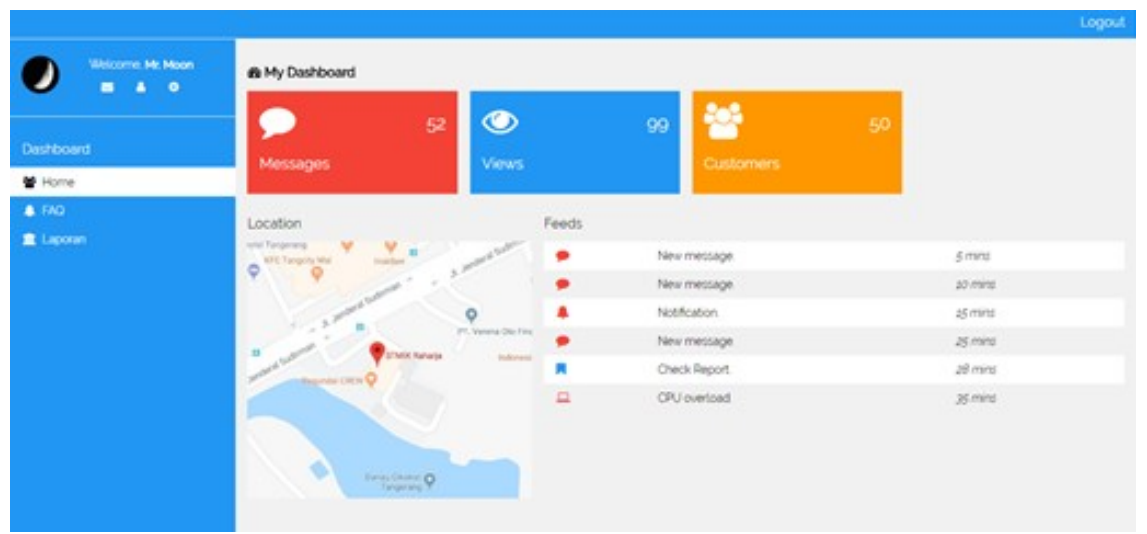

Figure 10. CS Admin Start Page view

Figure 10, is the main page display where the page appears after the user has logged in. CS Admin Main Page is a home menu like the picture below that contains the number of incoming messages, how many times the admin login, how many subscribers have interacted with the CS Admin, location and feeds. The access rights that the CS Admin has is to access the query data from the customer, and create a report for the manager.

\subsubsection{Employee Start Page display}

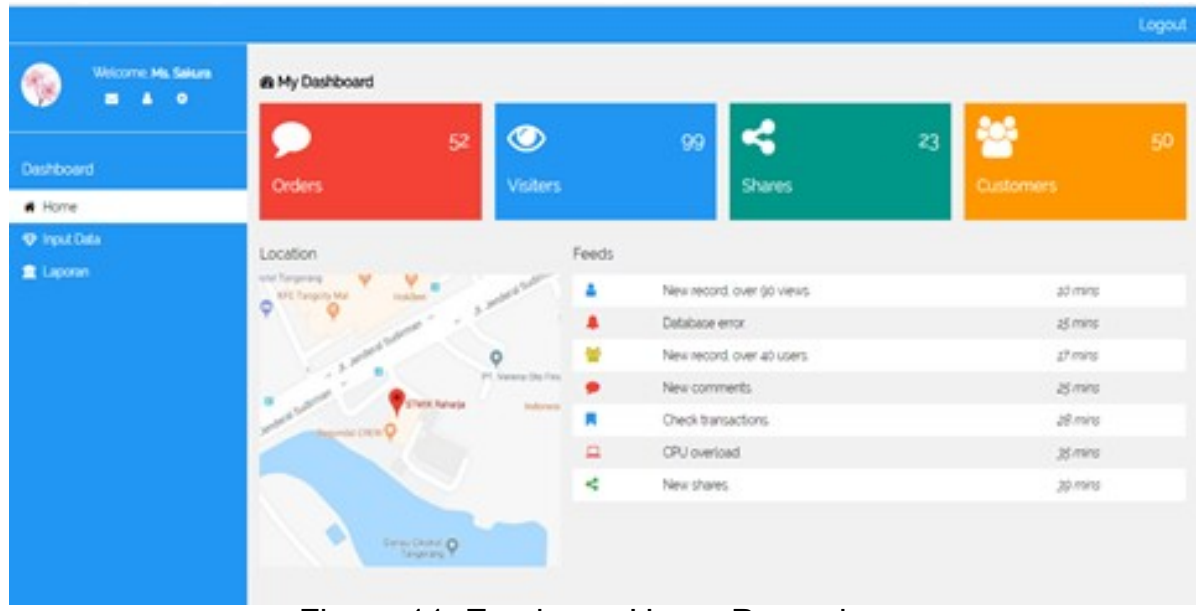

Figure 11. Employee Home Page view

Figure 11, is the main Page view of the employee's website after logging in, where there is a home menu like the picture below that contains the number of orders, number of visitors, number of shares, number of subscribers, location, and feeds. Employee-owned permissions are to access customer data, input item data, process orders, and generate reports for managers.

\section{Conclusion}

The results of analysis and design have been successfully created a system of information Customer Relationship Management (CRM) Web-based, can be taken 3 (three) conclusions as follows. The results of analysis and design have been successfully created a system of information Customer Relationship Management (CRM) Web-based, can be taken 3 (three) conclusions as follows:

1. With a system of information Customer Relationship Management (CRM) This webbased provides convenience to employees in the processing of data, processing of 
reports and delivery of information to customers.

2. Make it easy for CS admins to manage customer inquiries, as well as respond to customer inquiries easily, as there are media that can be used in communicating.

3. With this system provides convenience for customers to get the latest information about the product from the company, make a reservation, and convey questions and complaints to the company, which is recorded neatly in the system.

4. With this system the company is able to know the customer's wishes in depth, so that the company can strive to improve the performance of its company, to be able to maintain old customers and get new customers.

\section{References}

[1] Danardatu, A. H. (2011). Pengenalan Customer Relationship Management (CRM). IImuKomputer. Com. Diakses tanggal, 4.

[2] Claudia, C., Suyanto, M., \& Prihatini Sihotang, F. (2018). Sistem Informasi Manajemen Hubungan Pelanggan Pada CV. Shannon Otopart Palembang.

[3] Saputro, H., \& Tamrin, T. (2018). Implementasi Customer Relationship Management Untuk Optimasi Pelayanan Pelanggan Makanan Tradisional Rengginang Berbasis Web Dan TAWK. Jurnal SITECH: Sistem Informasi dan Teknologi, 1(2), 63-72.

[4] Sugiarni, N. L. M., Pramana, D., \& Puspita, N. N. H. (2015). Implementasi CRM (Customer Relationship Management) Pada Sistem Informasi Travel X Berbasis Web. Jurnal Sistem dan Informatika (JSI), 9(2), 51-59.

[5] Rachmatsyah, A. D., \& Merlini, D. (2017). Perancangan Sistem Informasi Administrasi Surat Berbasis Desktop Pada Kantor Notaris Hoiril Masuli, Sh, M. Kn. Jurnal Sisfokom (Sistem Informasi dan Komputer), 6(2), 130-136.

[6] Amin, A. I., Darmawan, E., \& Budianto, H. (2018). IMPLEMENTASI CRM (CUSTOMER RELATIONSHIP MANAGEMENT) PADA SISTEM INFORMASI RESERVASI FOTOGRAFI BERBASIS WEB DI TOKO AINI PHOTO KUNINGAN. NUANSA INFORMATIKA, 10(2).

[7] Rahman, A. A., Supaidi, A., Aslamiah, I., \& Ibrahim, A. (2018). IMPLEMENTASI CUSTOMER RELATIONSHIP MANAGEMENT (CRM) PELAYANAN PELANGGAN (CORPORATE) DIVISI BGES PADA Indonesia TELKOM WITEL SUMSEL. JRMSIJurnal Riset Manajemen Sains Indonesia, 9(1), 72-78.

[8] Simbolon, F. (2014). Model Pengukuran Kinerja Customer Relationship Management dalam Industri Perbankan. Binus Business Review, 5(1), 278287.Simbolon, F. (2014). Model Pengukuran Kinerja Customer Relationship Management dalam Industri Perbankan. Binus Business Review, 5(1), 278-287.

[9] Suryadi, A. I., Yulia, Y., \& Purbowo, A. N. (2017). Pembuatan Aplikasi Customer Relationship Management Berbasis Website untuk Membantu Penjualan dan Analisis Penjualan Produsen Sepeda. Jurnal Infra, 5(1), 217-223.

[10] Bahri, S., \& Dalis, S. (2018). Rancang Bangun E-Enrollment Berbasis Web Menggunakan Customer Relationship Management (CRM) Pada Sekolah Dasar Islam Terpadu. Jurnal Teknik Komputer, 4(1), 205-211.

[11] Yuniati, S. (2012). Peta Konsep (Mind Mapping) dalam Pembelajaran Struktur Aljabar. Gamatika, 3(2). 